UDC: 378.147.091.3:001.9(100)

DOI: https://doi.org/10.24195/2414-4665-2017-8-10

\begin{abstract}
Alla Kolomiiets,
Dr.hab. in Pedagogy, professor,

Vice-rector for Scientific Work,

Vinnytsia State Pedagogical University named after Mykhailo Kotsiubynsky,

32, Ostrozhsky Str., Vinnytsia, Ukraine,
\end{abstract}

Dmytro Kolomiiets,

PhD (Candidate of Pedagogical Sciences), associate professor, Professor of TEESVA Chair,

Vinnytsia State Pedagogical University named after Mykhailo Kotsiubynsky,

32, Ostrozhsky Str., Vinnytsia, Ukraine,

Yevhen Gromov,

PhD (Candidate of Pedagogical Sciences), lecturer,

Head of Research and Development Department,

Vinnytsia State Pedagogical University named after Mykhailo Kotsiubynsky,

32, Ostrozhsky Str., Vinnytsia, Ukraine

\title{
IMPLEMENTATION OF THE LATEST WORLD-CLASS SCIENTIFIC ACHIEVEMENTS IN TRAINING PROCESS OF FUTURE TEACHERS
}

The paper deals with the main directions and methodological principles of future pedagogues' professional skills improvement, enhancement of their scientific outlook, and development of their methodological culture by means of the implementation of the latest scientific achievements into the content of the training process of future teachers. The principal directions are as follows: implementation of fundamental sciences and investigations results in corresponding sections of studied subject matters; applying latest psychological and pedagogical achievements to future teachers' methodological training; using constantly developing information technologies potential for the improvement of the content and forms of the educational process organization.

Keywords: teacher training, scientific achievements, implementation, research and development, pedagogical university, education contents.

\section{Introduction}

At the contemporary stage of the Ukrainian society development it has been publicly and officially recognized that traditional education system is in deep crisis. It goes without saying that education system crisis is just a part of the global civilization crisis. Present civilization may be characterized by crises of economical, ecological, energetic, informational, social and national character. The possibility of the successful overcoming of these crises and conflicts is mostly determined by the level of society erudition and culture. The given specificity of the society development puts forward the new requirements for the educational paradigm: the main educational objectives are considered as the formation and development of personality by means of learning; focus on reaching the new educational level of both an individual and the society in general; broadening of every school and university student's scientific outlook.

The requirements to future teachers' training quality level demand subordination of higher educational process not only to the task of informational satiation but also to the tasks of students' thinking culture formation, their intellectual potential development, research skills and creative designing abilities. In other words, the educational process in a pedagogical higher educational institution must be aimed at the tight connection with scientific ac- tivity, must turn into the scientific-pedagogical process. To reach this goal university teachers, instead of being retranslators of out-of-date knowledge, must become researchers combining educational and scientific activities [1, p.11].

Analyzing the latest publications on this issue one can mark that Ukrainian official educational policy is called upon changing the society's attitude to education and its scientific maintenance from the standpoint of educational sphere reformation perspectives to meet the requirements of Euro-integration and globalization challenges of the $21^{\text {st }}$ century, explorative-innovative character of civilization movement, cultural-historical, sociopolitical, socio-economic, scientific and technical processes in the Ukrainian society [6, p. 5]. It has been mentioned in the National Report on Present State and Development Perspectives of Education in Ukraine that "the main role in guaranteeing the Ukrainian society's innovative development belongs to the spheres of education and scientific research and development" [6, p.25]. That is why it is absolutely necessary to create up-to-date scientific and methodological support of changes in the sphere of education, which must be secured by profound studies in the fields of Education, Pedagogy and Psychology [7, p.26]. 
Ukrainian researchers I. Kashaiev, R.P uhatchov, M. Faschevsky pay special attention to the necessity of integration of scientific achievements into the educational process considering such an integration as an indispensable prerequisite for students' professional competencies growth [2, p. $178 ; 7$, p. 365]. Foreign scholars also emphasize that educational process and implementation of scientific investigations in higher educational institutions must be indissolubly connected, especially at universities $[1$, p. $12 ; 3$, p. 308].

\section{Unsolved aspects}

There still remain some unsolved aspects of this issue. The point is that these works mostly concern the matters of applying either achievements in the fields of education and psychology or the results of research and development activities of teachers and students themselves to the educational process. At the same time these works do not cover the issue of the implementation of the latest world-class scientific achievements into the process of professional training of future teachers who are called upon the formation of young generation's scientific outlook. That is why arrangements aimed at the renewal of the content, forms and methods of future teachers training are urgently needed. According to some pedagogical investigations [4, p. 48; 5, p. 59], traditional system of higher pedagogical education which is focused on subject-teachers, is unable to solve these assignments at the new high quality level. These challenges require new methodological approaches to the organization of future teachers' professional training as well as special methods of implementation of the latest world-class scientific achievements in the content and pedagogical technologies of future teachers' training.

\section{Aim of the article}

The paper aims to determine the principal directions and methodological bases for the implementation of the latest world-class scientific achievements in the content of training of future natural sciences teachers.

\section{Objectives:}

- determining the level of the students' awareness of the latest world-class scientific achievements in the relevant scientific fields as well as the level of their readiness to implement these achievements in the educational process;

- clarifying the factors which hinder the formation of the future teachers' readiness for implementation of the latest world-class scientific achievements in the content and organization of the educational process;

- confirming the necessity of changing the methodology of natural sciences teachers' training.

\section{Research methods:}

- profound analysis of the future natural sciences teachers' training programs content for the determination of the scope of the learning material devoted to the scientific achievements over the last $10-20$ years;

- questioning the graduates regarding their awareness of the latest scientific achievements in the relevant fields;
- observing the students' activities on finding and structuring information concerning modern scientific discoveries;

- testing graduates in order to determine the percentage of those who are conscious of the need to update professional knowledge and skills which were acquired within the scope of training process.

\section{Research Results and their Discussion}

Within last 10-15 years in every branch of science there have been obtained definite results which have resulted in cardinal changes in the life of the world society. Among them there are fundamental achievements in the fields of Mathematics, Biology, Physics, Chemistry as well as applied results in the spheres of InformationCommunication Technologies, Psychology, Pedagogics, etc. The significance of these results for the further development of science and practice is determined by the rapidity of their applying in the corresponding branches of knowledge. Though, as we can see from the analysis of secondary school textbooks on natural and mathematical disciplines, they present neither the newest scientific findings nor the results of researches which were obtained even 30-40 years ago. At the same time, the practice of higher school training implements up-to-date results of natural, socio-cultural and psychological-pedagogical investigations too slowly. It goes without saying that such sluggish implementation of new scientific achievements into the educational process retards society development rates, causes detachment of theory, education and practice. Very often a teacher is not even aware of the latest achievements in the branch of science which he/she teaches. He/she is not always psychologically ready for accomplishing complicated pedagogical assignments connected with polysubjectiveness and multiculturalism of student groups. Subject-teachers' methodological readiness for implementation of innovative learning technologies in educational process needs substantial improvement as well.

To solve the detachment problem of theory, education and practice we suggest application of specialized measures which are aimed at the implementation of the latest scientific investigations achievements into the content and technologies of future teachers training. We suggest considering the following principal directions:

1) implementation of the research results of fundamental sciences in the corresponding sections of educational disciplines;

2) applying latest psychological and pedagogical achievements to future teachers' methodological training;

3) using constantly developing information technologies potential for the improvement of the content and forms of educational process organizing.

For putting these assignments into effect we recommend lecturers to supplement their lecture-courses with additional seminars entitled "Latest scientific achievements in the field of ...". Students themselves must be involved in the process of search and retrieval of corresponding theoretical materials. They are used to looking 
for necessary information in the Internet. They can quickly structure it according to a certain chronological and logical consecution, prepare computer-based presentations and make interesting scientific reports.

As it can be seen from practice such independent research and development activity is interesting and effective for the enhancement of future teachers' scientific outlook. Such an activity forms students' readiness for making scientific investigations. This readiness is regarded as students' awareness of advantage of scientific realization of their professional development over simple accumulation of knowledge and skills. Scientific research work enables brighter manifestation of both students' and teachers' creative peculiarities and possibilities.

The second significant direction of future teachers' professional training quality improvement is applying latest psychological and pedagogical achievements to future teachers' methodological training. In Psychology, this direction is realized through up-to-date technologies of self-improvement, self-development and selforganization. In Pedagogy, we deal with innovative technologies and teaching techniques.

The best results are ascertained in introduction of innovative educational technologies in teachers' training and developing their innovative teaching skills. Certain materials concerning innovations in education were introduced into several disciplines, thus the future teachers' training process now is being realized on innovative base. In educational practice, we widely use such technologies as project learning, situational learning, cooperative learning, discussions, business games, brainstorming methods and others.

Teaching various disciplines, we still more confidently use network technologies of learning-aimed open systems (electronic libraries, social networks, correspondence and mobile learning technologies, research and development automation technologies) as well as SMARTtechnologies (interactive boards, SMART Notebook Software, digital document-cameras, interactive questionnaire systems, class controlling SMART-systems, etc.)

The effectiveness of all aforementioned teaching technologies was investigated and asserted in dozens of dissertations. Nevertheless, it has also been mentioned, that scientific constituent part of innovative technologies applying has no reflection in future teachers' consciousness. According to lecturers governing teaching practice, almost every student has difficulties with solving problem tasks. Scilicet, graduates of pedagogical higher educational istitutions cannot use pedagogical science achievements for comprehension of methods and results of their own work. The acquisition of such skills is not provided in their training curriculum.

According to our observations the vast majority of future teachers cannot settle difficult pedagogical assignments relying on scientific achievements. It is noticeably shown in creative activity while attempting to ground scientifically certain innovations in the sphere of subject techniques.

Therefore, it was decided to clarify the pedagogical university graduates' awareness of the latest world-class scientific achievements and the level of their aspiration for the implementation in their future professional activities the latest scientific achievements in the corresponding fields, innovative pedagogical technologies, and the capabilities of modern information technologies in updating the content and forms of the educational process organization.

Having analyzed the survey results, we divided the $4^{\text {th }}$ year students of the Natural Sciences Faculty into three groups (see Fig. 1):

- the first group ( 1 - blue color in circular diagrams) involves those students who do not know and do not consider it necessary to learn more;

- the second group $(2$ - red color in circular diagrams) involves those students who know little and would like to know more, but are not inclined to implement their knowledge in practice;

- the third group ( 3 - green color in circular diagrams) involves those students who consider their awareness insufficient, and therefore they are determined to replenish knowledge and constantly develop their skills in future professional activities.

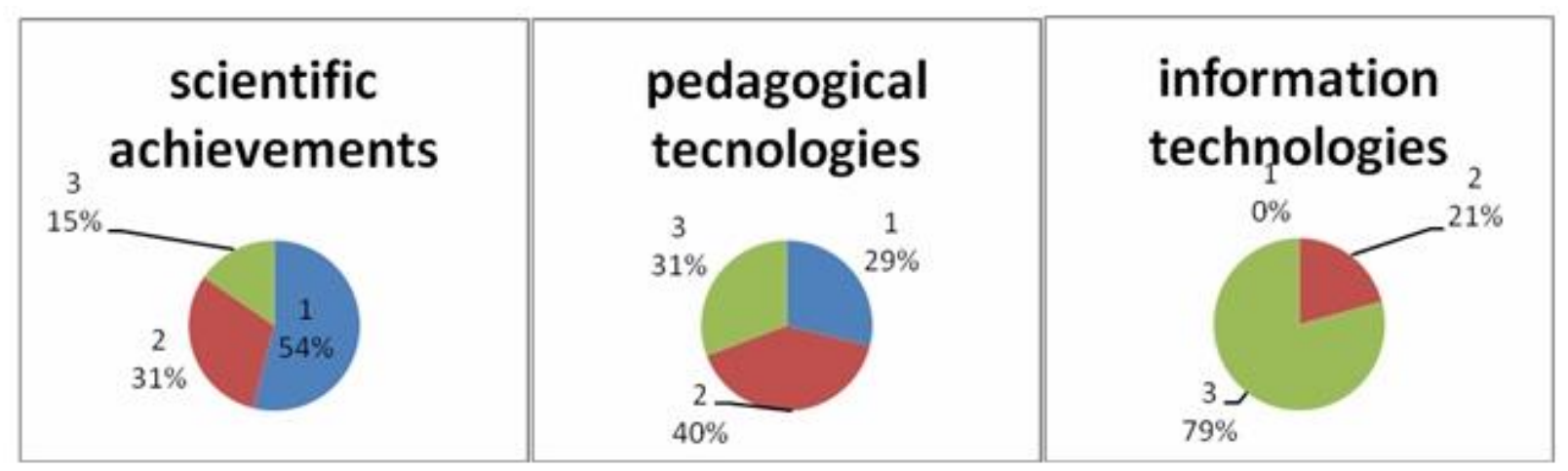

Fig. 1 Distribution of future teachers by levels of readiness for implementation of the latest scientific achievements in the educational process 
Empirical evidence suggests that there are significant disadvantages in the training of future natural sciences teachers. The comparison of the circular diagrams indicates that the worst situation has arisen with regard to the implementation of the latest natural sciences achievements in the content of corresponding school disciplines. More than half of the pedagogical university graduates do not know and are not interested in the latest achievements in the relevant scientific fields, they are not ready to make efforts to expand their scientific outlook.

Almost a third of the pedagogical university graduates do not see the need to find and apply more effective methods, forms, means and technologies of learning in specific situations of the educational process. It is also alarming that having almost absolute awareness of the capabilities of information and communication technologies for the improvement the quality of the educational process more than $20 \%$ of the students do not plan to use these means in their professional activities.

Among the factors that hinder the formation of future teachers' readiness for the implementation of scientific achievements in the content and organization of the educational process we can highlight the following:

1) Imperfection of philosophical education which causes weakness of categorical thinking. Pedagogical university course of Philosophy can hardly reach its initial goal. This circumstance negatively affects students' logical-methodological culture formation. Students cannot reach the level of categorical generalization so they dwell on the level of isolated facts fixation. It causes the formation of the conviction that empiric reliability is the most significant index of Truth and secures maximal proximity to objective reality. That is why we recommend additional courses on cognition theory, logics and scientific thinking.

2) Even until now a student is considered to be an object of education. Much more attention should be paid to a student regarding him/her as the subject who is directly responsible for education. The student's main responsibility is the intensive involvement into cognition of the world science and culture by means of libraries and mass-media, including the Internet. To attach students to World's Culture they must be provided with compulsory regular lectures on the matters connected with general scientific and cultural achievements of Humanity. Students must possess profound knowledge not only of the studied subject fundamentals but must be thoroughly acquainted with its history and methodology.

\section{REFERENCES}

1. Esareva, Z.F. (1975). Vzaimodeistvie nauchnoy $i$ pedagogicheskoy deyatelnosti prepodavatelya universiteta [Interaction of scientific and pedagogical activities of a university teacher]. Leningrad [in Russian].

2. Kashaev, I.O. \& Puhachov, R.V. (2014). Vprovadzhennia rezultativ naukovykh doslidzhen $\mathrm{u}$ navchalny protses [Implementation of scientific investigations re-
3) Unfortunately we must admit that in pedagogical higher educational institutions learning is detached from research and development activity. Students are taught teaching skills apart of investigative ones. The necessity of introduction of methodological knowledge into future teachers' training process has become obvious recently because experience alone is not enough for the solution of problem assignments. Here we need knowledge which can not only enrich future teachers' mentality but foster awareness of their activity and decision on the most effective strategy of socio-pedagogical problems solution.

There are some reasons causing appealing to pedagogical methodology:

1) The necessity for reorientation from technocratic training to the development of future teacher's personality and mastering culture and methodology of pedagogical work;

2) Higher education system is determinative for both a society and a country; it is the most important system of science implementation. That is why it is necessary to tie up different spheres of education and science which are noticeably detached now;

3) High-quality informatization of education and introduction of other innovative educational technologies are impossible without knowledge normalizing and methodological generalization.

Now it is quite evident that an educator cannot be a highly skilled teacher without methodological culture, clear idea of science, ability to use science for the benefit of practice.

\section{Conclusion}

According to the research outcomes, it has been revealed that more than half of the respondents do not know and are not interested in the latest achievements in the relevant scientific fields, they are not ready to make efforts to expand their scientific outlook.

It has been found that the imperfection of philosophical education which causes weakness of categorical thinking, the fact that a student is still considered as an object of education, as well as the fact that learning is detached from research activities are the main factors that hinder the formation of future teachers' readiness for the implementation of scientific achievements in the content and organization of the educational process.

Considering the research outcomes, we believe that all these factors negatively affect the process of training future teachers of natural sciences, which is why there is the necessity of changing the methodology of natural sciences teachers' training.

sults into educational process]. Nauka i tehnika Povitrianyh Syl Zbroinyh Syl Ukrainy - Science and Technique of Ukrainian Air Forces, 2, 177-179 [in Ukrainian].

3. Klimova, N.V. (2011). Integratsia vuzovskoy nauki i uchebnogo protsesa $\mathrm{v}$ usloviah harmonizatsii sistemy vyschego obrazovania [Integration of higher school science and educational process in conditions of higher 
education system harmonization]. Fundamentalnye issledovania - Fundamental Investigations, 12, 306-301 [in Russian].

4. Kolomiets, A.M. \& Lazarenko, N.I. (2016). Suchasni metodolohichni pidhody v organizatsii vyschoi pedagogichnoi osvity [Modern methodological approaches to pedagogical higher education organization]. Naukovi visnyk Pivdennoukrainskoho natsionalnoho pedagogichnoho universitetu imeni K.D.Ushynskoho - Scientific Bulletin of South Ukrainian National Pedagogical University named after K. D. Ushinsky, 3, 47-52 [in Ukrainian].

5. Kushnir, V. (2012). Metodolohichna pidhotovka vchytelia [Methodological training of teachers]. Naukovi zapysky Kirovogradskoho derzhavnoho pedagogichnoho universytetu imeni V.Vynnychenka - Scientific Bulletin of Kirovograd State Pedagogical University named after V.Vynnychenko, 106, 58-74 [in Ukrainian].

6. Kremen, V. G., Luhovy, V.I., Gurzhii, A.M., Savchenko, O.Y. (2016). Natsionalna dopovid pro stan $i$

\section{ЛІТЕРАТУРА}

1. Есарева 3. Ф. Взаимодействие научной и педагогической деятельности преподавателя университета: Автореф. дис.... докт. пед. наук. / З. Ф. Есарева. Л., 1975. -20 c.

2. Кашаєв I. Впровадження результатів наукових досліджень у навчальний процес / I. О. Кашаєв, Р. В. Пугачов // Наука і техніка Повітряних Сил Збройних Сил України. - 2014. - № 2 (15). - С. 177 179.

3. Климова Н. В. Интеграция вузовской науки и учебного процесса в условиях гармонизации системы высшего образования / Н. В. Климова // Фундаментальные исследования / Н.В. Климова. - 2011. - № 12 (ч. 2). - С. 306-310.

4. Коломієць А. М. Сучасні методологічні підходи в організації вищої педагогічної освіти / А. М. Коломієць, Н. I. Лазаренко // Науковий вісник Південноукраїнського національного педагогічного університету імені К. Д. Ушинського. - Випуск 3(110). Серія : Педагогіка. - Одеса : ПНПУ, 2016. - С. 47-52.

5. Кушнір В. Методологічна підготовка вчителя / В. Кушнір // Наукові записки Кіровоградського дер- perspektyvy rozvytku osvity $v$ Ukraini [National report about contemporary condition and perspectives of development of education in Ukraine]. Kyiv: Pedagogichna dumka [in Ukrainian].

7. Fashchevsky, M.I. (2013). Integratsia naukovyh dosiagnen u navchalny protses jak neobhidna peredumova zrostannia fahovyh kompetentsij studentiv [Integration of scientific achievements into educational process as a necessary precondition of students' professional competences growth]. Proceedings from Mizhnarodna Naukovometodychna konferentsia "Vid vykladannia dystsyplin do osvoennia nauk: transformatsia zmistu, tehnolohij osvitnioji dijalnosti ta rozvytok pedagogichnoi maisternosti»International Scientific and Methodological Conference "From Disciplines Teaching to Sciences Mastering: Transformation of the Contents and Technologies of Educational Activity and Pedagogical Skills Development». (pp. 365-366). Kyiv: Ministry of Education and Science of Ukraine [in Ukrainian].

жавного педагогічного університету імені Володимиpa Винниченка. Серія: Педагогічні науки. - 2012. Вип. 106. - С. 58-74.

6. Національна доповідь про стан і перспективи розвитку освіти в Україні / Нац. акад. пед. наук України ; [редкол.: В. Г. Кремень (голова), В. І. Луговий (заст. голови), А. М. Гуржій (заст. голови), О. Я. Савченко (заст. голови)] ; за заг. ред. В. Г. Кременя. Київ : Педагогічна думка, 2016. - 448 с.

7. Фащевський М. І. Інтеграція наукових досягнень у навчальний процес як необхідна передумова зростання фахових компетенцій студентів / М. І. Фащевський // Від викладання дисциплін - до освоєння наук: трансформація змісту, технологій освітньої діяльності та розвиток педагогічної майстерності : зб. матеріалів наук.-метод. конф., 31 січ. 2013 р. / М-во освіти і науки України, ДВНЗ «Київ. нац. екон. ун-т ім. Вадима Гетьмана» ; [редкол.: А. М. Колот, О. І. Олексюк, Т. В. Гуть]. - Київ: КНЕУ, 2013. C. 365-366. 
Алла Миколаӥвна Коломієць,

доктор педагогічних наук, професор, проректор з наукової роботи, Вінницький державний педагогічний університет ім. М.М. Коцюбинського, вул. Острозького, 32, м. Вінничя, Украӥна,

Дмитро Іванович Коломієць, кандидат педагогічних наук, дочент, професор кафедри ТОЕБЖД, Вінницький державний педагогічний університет ім. М.М. Коиюбинського, вул. Острозького, 32, м. Вінниия, Украӥна,

Євген Володимирович Громов,

кандидат педагогічних наук, викладач, начальник наукового відділу, Вінницький державний педагогічний університет ім. М. М. Коџюбинського, вул. Острозького, 32, м. Вінниия, Україна

\section{ІМПЛЕМЕНТАЦІЯ НОВІТНІХ НАУКОВИХ ДОСЯГНЕНЬ СВІТОВОГО РІВНЯ У ПІДГОТОВКУ МАЙБУТНІХ УЧИТЕЛІВ}

На сучасному етапі розвитку українського суспільства на державному рівні визнано, що традиційна система освіти перебуває в стані кризи. До того ж, очевидно, що криза системи освіти - це лише частина глобальної цивілізаційної кризи. Нинішню цивілізацію характеризують кризи економічного, екологічного, енергетичного, інформаційного, соціального та національного характеру. Можливість успішного подолання цих криз і конфліктів багато в чому визначається рівнем освіченості та культури суспільства. Зазначена специфіка розвитку суспільства диктує нові вимоги до освітньої парадигми: основними цілями освіти стають формування та розвиток особистості засобами навчання; орієнтація на досягнення якісно нового рівня освіченості кожної особистості та суспільства загалом; розширення наукового світогляду кожного учня й студента. Вимога підвищення якості підготовки майбутнього вчителя вимагає підпорядкувати навчальний процес у ВН3 не стільки завданню інформаційного насичення, скільки формуванню культури мислення студентів, розвитку інтелектуального потенціалу особистості, дослідницьких навичок і вмінь творчого конструювання. Тобто навчальний процес у педагогічному ВНЗ має бути спрямованим на тісний зв'язок з науковою діяльністю і стати науково-педагогічним. Потрібні нові методологічні підходи до організації професійної підготовки майбутніх учителів і спеціальна методика імплементації новітніх результатів наукових досліджень у зміст і технології підготовки майбутніх учителів. Напрямами розв'язання проблеми відірваності теорії, освіти і практики вважаємо спеціальні заходи щодо імплементації новітніх результатів наукових досліджень у зміст $\mathrm{i}$ технології підготовки майбутніх учителів. До таких напрямів відносимо: імплементацію результатів досліджень фундаментальних наук у відповідні розділи навчальних дисциплін; упровадження новітніх психолого-педагогічних досягнень у методичну підготовку майбутніх учителів; використання можливостей інформаційно-комунікаційних технологій, що постійно розвиваються, в удосконаленні змісту та форм організації навчально-виховного процесу. Зазначені заходи не лише розширюють науковий світогляд майбутніх педагогів, а й розвивають методологічну культуру, без якої неможлива висока якість педагогічної освіти.

Ключові слова: підготовка вчителів, наукові досягнення, науково-дослідна робота, імплементація, педагогічна освіта, зміст освіти.

Submitted onn June, 15, 2017 